This item was submitted to Loughborough's Research Repository by the author.

Items in Figshare are protected by copyright, with all rights reserved, unless otherwise indicated.

\title{
Reconciling marketing with political science: theories of political marketing
}

PLEASE CITE THE PUBLISHED VERSION

PUBLISHER

(C) Elsevier

LICENCE

CC BY-NC-ND 4.0

REPOSITORY RECORD

Wring, Dominic. 2019. "Reconciling Marketing with Political Science: Theories of Political Marketing”. figshare. https://hdl.handle.net/2134/1089. 
This item was submitted to Loughborough's Institutional Repository by the author and is made available under the following Creative Commons Licence conditions.

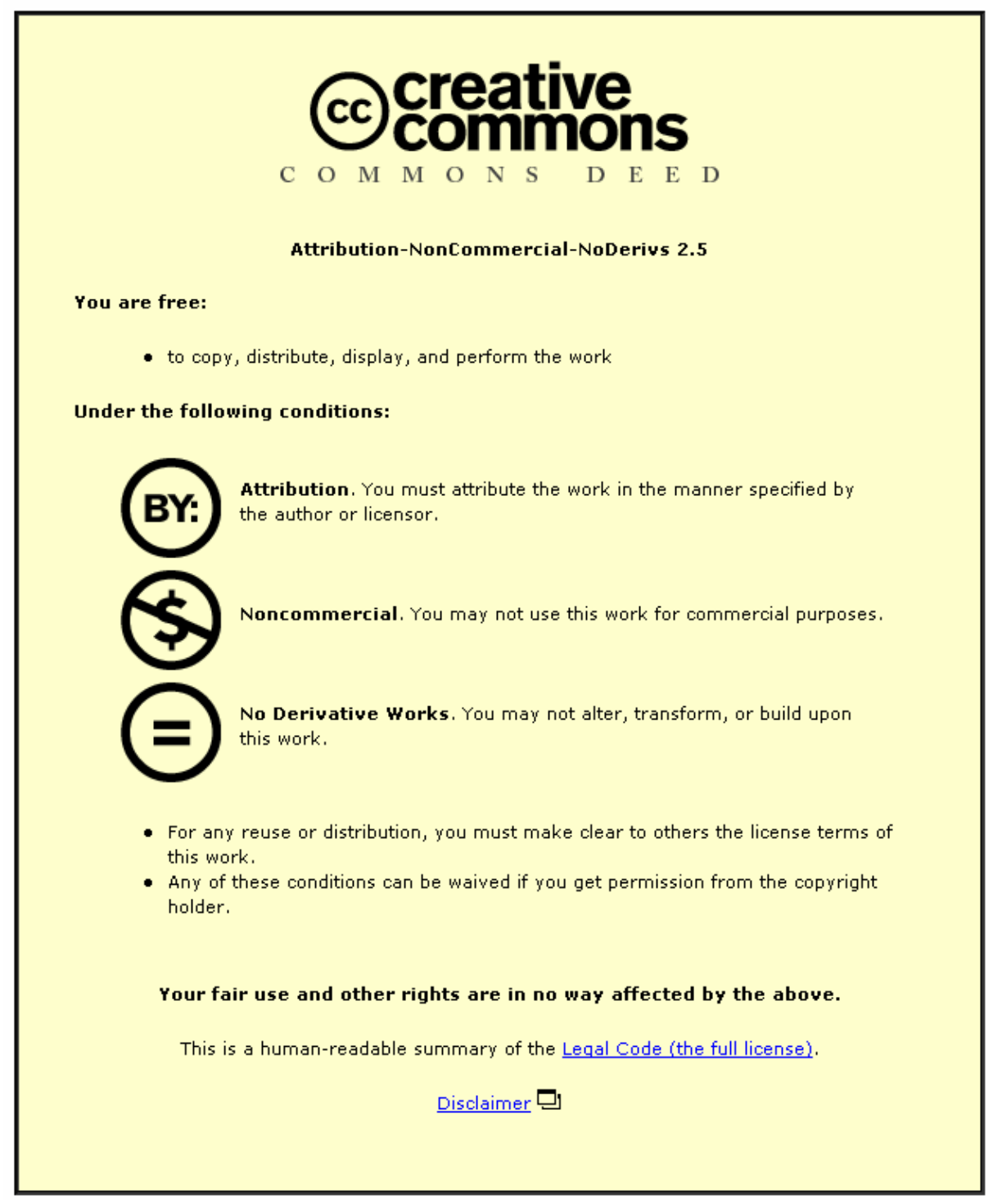

For the full text of this licence, please go to: http://creativecommons.org/licenses/by-nc-nd/2.5/ 


\title{
ㅁoughborough University
}

\author{
Reconciling Marketing with Political Science: Theories of Political \\ Marketing. \\ Journal of Marketing Management, 1997, Vol 13, pp.651-663
}

\section{Dominic Wring}

This paper has two broad aims: to trace the theoretical development of political marketing and then demonstrate how these concepts can be used in the analysis of election campaigns. Electioneering is not the sole manifestation of marketing in politics but it is the most obvious, a point underlined by recent work addressing the prominent role now played by political marketing in a parliamentary democracy like Britain (Franklin 1994; Kavanagh 1995; Scammell 1995). Whilst much of this material understandably concentrates on the once neglected work of campaign practitioners, the more theoretical explorations of the intersection between marketing and politics have tended to appear in management journals (Shama 1976; Smith and Saunders 1990; Butler and Collins 1994). This paper intends to explore the relationship from a political science perspective. 


\section{Defining Political Marketing.}

In their seminal article, Kotler and Levy (1969) argued that elections should be one of the new arenas of marketing interest: "Political contests remind us that candidates are marketed as well as soap.” However the earliest recorded use of the term "political marketing” did not appear in a formal management study but in the pioneering work of political scientist Stanley Kelley which charted the emergence of the professional campaign industry in the United States. Commenting on the activities of the first election consultancies, Kelley wrote:

\footnotetext{
“The team relies heavily but not entirely upon their own intuitive feel for providing political marketing conditions. They pride themselves on having "good average minds" that help them to see things as the average man sees them.” (Kelley 1956: 53)
}

In spite of the opposition from marketing purists those in sympathy with the 'broadening' thesis began to attempt to clarify, refine and establish the subfield of political marketing. By the mid-1970s American scholars such as Avraham Shama $(1974 ; 1976)$ and the prolific Philip Kotler (1975) were to the fore in developing theoretical foundations for the subject. Similarly experts in Europe began to consider the political dimension to marketing, positing the view that an exchange relationship existed between democratic elites and their voters (O'Leary and Iredale 1976). By the mid-1980s a steady stream of research discussing the emergence of the phenomenon 
helped confirm its importance (Mauser 1983; Newman and Sheth 1985). Writing in 1988 David Reid concluded that:

"In western terms, although seldom recognised by politicians, the problem of getting elected is essentially a marketing one. Political parties must determine the scope and the most effective way of communicating its benefits to a target audience.” (Reid 1988)

\section{Marketing and Political Marketing.}

Seymour Fine identifies the 1985 decision of the American Marketing Association (AMA) to redefine its central concern as a milestone in the integration of social (and political) issues into mainstream marketing thinking. New phraseology added the crucial word "ideas" to the list of legitimate product concerns: "Marketing is the process of planning and executing the conception, pricing, promotion and distribution of ideas, goods and services to create exchanges that satisfy individual and organizational objectives” (cited in Fine 1992: 1).

Since its revision the American definition has continued to enjoy wide currency in the literature in spite of various complex arguments over what the precise nature of the subject is, is not and ought to be (Hunt 1976; Whyte 1988; Hooley et al. 1990). The British equivalent of the AMA statement, as agreed by the Chartered Institute of Marketing (CIM), places similar emphasis on the notion that organisational success is an integral part of strategic concerns: firms do not seek to satisfy consumers out of altruism but 
from a desire to realise their own profit-making goals. To the CIM marketing is "the management process responsible for identifying, anticipating and satisfying customer requirements profitably" (cited in Whyte 1988). The British and American definitions are useful in that they counteract the crude and oversimplistic belief that marketing is simply about firms giving their customers what they want. Such a cliché may convey clarity but it obscures more complex truth. And because some in political science (not to mention other disciplines) may have misunderstood marketing in this way, it helps explain why relatively few in the field have sought to use it as a tool of electoral analysis.

Marketing then is a process in which the notion of "consumer focus" plays a major strategic role but not to the exclusion of organisational needs. Compared with over-simplistic customer centred understandings of the subject, this theoretical interpretation fits more easily with the world of “realpolitik”. In analysing the electoral market Adrian Sackman emphasises this point, arguing that: "Marketing is thus built upon a paradox; it starts with the customer, is directed at the customer, but is fundamentally concerned with the satisfaction of the producer's own interests” (Sackman 1992). Such sentiments resemble J.K.Galbraith's stricture that marketing and advertising are activities governed and to some extent created by producer groups (Galbraith 1969). In political science this view is reflected in theoretical considerations of competition which attempt to marry the need of the organisation (that is the party) to win support with its desire to maintain some degree of programmatic consistency between elections. 
Due to the peculiar nature of the environment in which they operate and despite the existence of "voter sovereignty", parties rather than firms are perhaps more adequately equipped to influence the deliberations of their market. Thus for Schattschneider elections are based around the organising principle that: "Democracy is a competitive political system in which competing leaders and organizations define the alternatives of public policy in such a way that the public can participate in the decision-making process” (Schattschneider 1960:141). This “realist” concept of democracy underpins Andrew Gamble's isolation of the key variables in the electoral marketplace:

"The actual workings of the mass democracy has divided the political market into two camps. There are those that compete for office and those that vote. Like the producers and consumers in economic markets it is a mistake to believe that these two functions are of equal importance. One is active, creative and continuous; the other is passive, receptive and intermittent.” (Gamble 1974:6)

It should be noted that whilst the statements of Schattschneider and Gamble place emphasis on a party's ability to shape voter preferences, neither commentator would deny the fundamental role the electorate play in determining outcomes within a competitive political market situation. Consequently, by emphasising the fact that it is both an organisational as well as consumer focused exercise, it is possible to understand the usefulness of marketing analysis to political scientists. 
Political Marketing: a definition.

Making reference to the management literature outlined in the previous section, it is possible to conceive of political marketing as:

"the party or candidate's use of opinion research and environmental analysis to produce and promote a competitive offering which will help realise organisational aims and satisfy groups of electors in exchange for their votes.”

At the root of this definition is a framework developed by Philip Niffenegger (1989). Designed with reference to the classic '4Ps' marketing model popularised by McCarthy (1960), Niffenegger's formulation highlights the roles played by environmental analysis, strategic tools like market research and ultimately the 'mix' of variables (product, promotion, place and price) in the design of political campaigns. The desirability of applying this 'mix' model to non-profit not to mention commercial marketing has been challenged by some who consider the 'Ps' approach outdated and inherently flawed (Blois 1987). Similarly, recognising the implicit difficulties in analysing the 'chimerical nature of elections', O’Shaughnessy cautions against the application of overly rigid marketing frameworks to politics (O'Shaughnessy 1990:4). Nevertheless, in spite of these objections, the Niffenegger framework has been adopted by Butler and Collins (1993) and other derivations of the mix model can be found in the work of Farrell (1986), Farrell and Wortmann (1987) and Newman (1994). 


\section{The Political Marketing Process.}

The political marketing process as outlined in Table 1 consists of four parts, namely the party (or candidate) organisation, the environment which conditions its development, the strategic mix it deploys, and ultimately the market it must operate in.

The Political Market.

Adopting the maxim of Schumpeter (1943) that democracy is primarily concerned with parties' “competitive struggle for (the) people’s vote”, Gamble contends that:

"The main components of the modern political market are three; the existence of a mass electorate; competition between two or more parties for the votes of this electorate; and a set of rules governing this competition.” (Gamble 1974:6)

Within the political market the key relationship is based around a concept central to marketing theory, namely that of exchange between buyer and seller. Thus citizens give their votes to politicians who, when elected, purport to govern in the public interest (Scott 1970; Lane 1993). In a modern democracy the right to vote, commonly associated with the age of majority, allows for a mass electorate which can typically number well into the millions. 
Table 1: The Political Marketing Process.

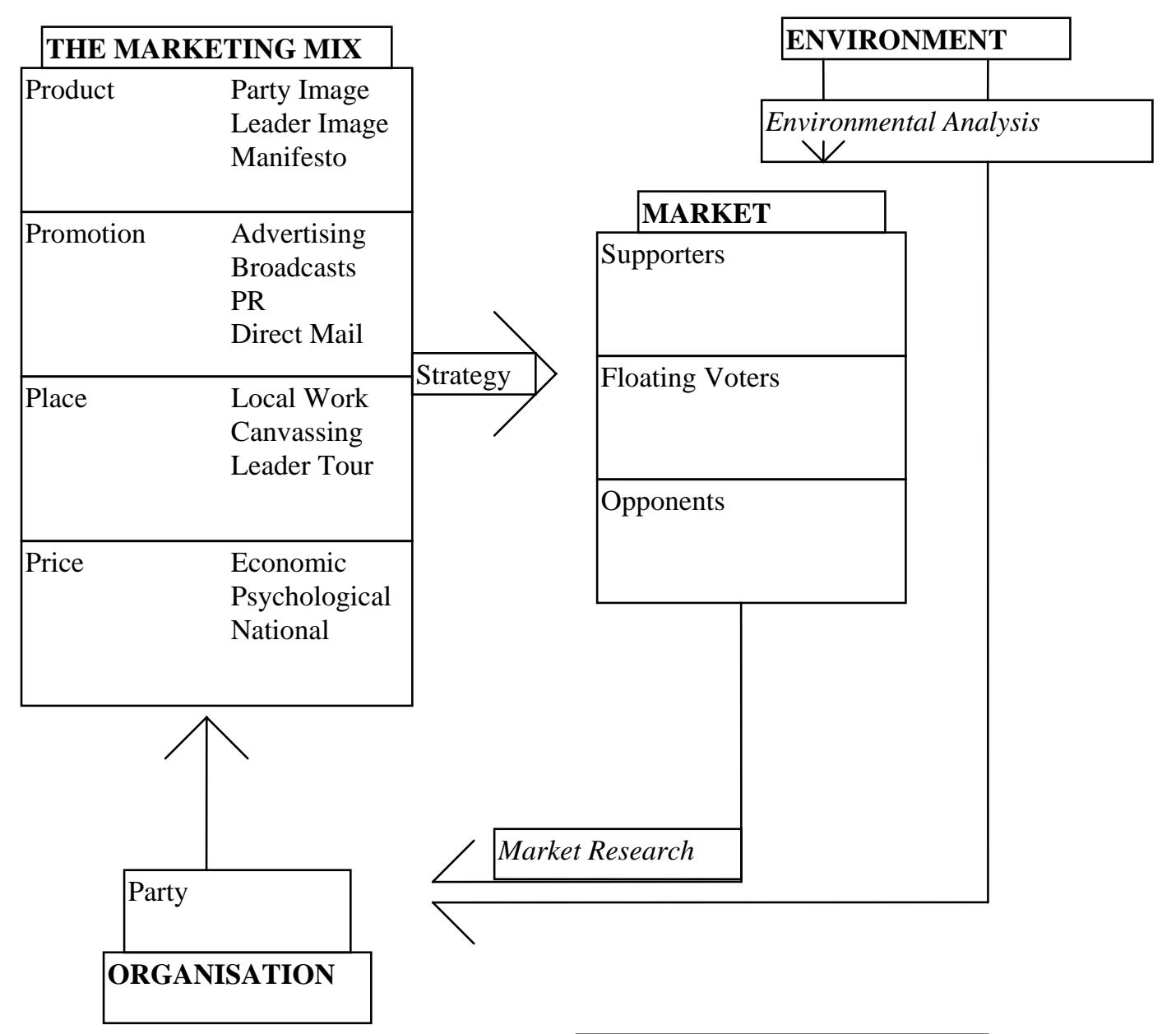

Adapted from Niffenegger (1990) 
Commercial markets tend to resemble the competitive structure found in an electoral system run on the grounds of proportionality as opposed to "first past the post”. This is not to argue that market criteria cannot be applied to a political situation such as that in Britain where purely majoritarian rules of voting operate. Indeed the need for the parties to maintain vote share as well as court new groups of "swing” voters is as relevant to participants in this system as it is to those operating under conditions of proportional representation.

Analysing the Environment.

On reflection it may appear that business organisations have a considerable advantage over politicians in respect of the amount of resources they are able to invest in analysing their environment. However such a perception of the marketing process perhaps discounts the immense amount of pertinent information which candidates and party professionals can draw upon in planning their campaigns. Broadsheet newspapers, specialist magazines and academic briefs offer a plethora of reports, analysis and opinion research material on which political strategists can base their decisions and better understand the economic, media and other factors shaping electors' concerns.

In contrast to the environment, which constitutes the "givens”, Hunt (1976) identifies what he calls “controllable factors", namely the collection of strategic decisions which an organisation can implement as part of its marketing programme. Together these variables are commonly known as the 
“mix”, a configuration that consists of the 4Ps: product, promotion, place and price.

\section{Product.}

The product is central to a marketing mix. In electoral terms the product, a "mix" of variables in its own right, combines three key aspects: "party image”, "leader image” and "policy commitments”. This configuration has been popularised by several analysts including Bob Worcester, head of the MORI polling organisation (Farrell and Wortmann 1987; Worcester 1987; Worcester 1991; Shaw 1994). Using survey data, Worcester points out the extent to which each element of the product influences opinion amongst different groups of voters. Thus where one segment might be susceptible to primarily issue based appeals others will display a preoccupation with the dimensions of leader or party image. Consequently Worcester represents the preoccupations of different electors in a series of triangular diagrams, the length of whose sides can be equated with the emphasis voters give to each of the product concerns (Worcester,1987).

The notion that politicians are increasingly using appeals based on the promotion of image at the expense of issues has become a common feature of journalists' election coverage. However such a view can no longer be regarded as a cliché and commands significant academic support (Biocca 1991; Franklin 1994). As Terence Qualter has concluded: “The marketing of politics means, of course, the reduction of politics to marketable images" (Qualter 1985:138). 
Whilst the notion of party image is built around factors such as the organisation's record in office, recent history and unity of purpose (Harrop and Shaw 1990), the substance underpinning the concept is more likely contained within the policy platform on which an election manifesto is based. In the last twenty years psephological research has begun to place greater emphasis on the rational choice notion of the elector as a consumer evaluating the issues and voting for the party most in tune with individual policy preferences (Himmelweit et al. 1985; Harrop 1986). However the overall picture is not simply one of a shift from party image to issue based explanations of voter choice because the situation has been complicated by another factor, that of leader image, which forms the third constituent in the political product mix.

Once a largely ignored factor in electoral research, the growing and potential future importance of leader image has been recognised in several studies into the increasing presidentialisation of British politics (Mughan 1993; Foley 1993; Crewe and King 1994). Media coverage of current affairs has helped extenuate this trend; as Philip Kotler comments: "Voters rarely know or meet the candidates; they only have mediated images of them. They vote on the basis of their images” (Kotler 1982).

\section{Promotion.}

Promotions form the most obvious part of a political marketing campaign. Misinformed commentators sometimes inflate the importance of advertising, 
the most recognisable communications tool, to the extent that it is held to represent the entire marketing process (see, for instance, Tyler 1987). Such a mistake fails to appreciate the complexities of a complete strategy, not to mention other parts of the promotional mix. Given the centrality of advertising within the modern marketing industry it is perhaps not surprising that its public profile is considerably higher than that of its "stablemates" in the fields of direct mail and public relations. Nevertheless, with the advent of modernised forms of the latter in the shape of "junk mail" and "spin doctors”, these parts of the promotional mix are beginning to gain increasing public prominence and particularly in the electoral arena.

The promotional mix can be divided into two principal parts commonly referred to as "paid" and "free" media. The term paid media covers all forms of advertising, be it in poster, print or broadcast form. It should be noted that, though the primetime television and radio advertising slots for Party Election Broadcasts (PEBs) in Britain are free, those parties which qualify for them are technically in receipt of a state subsidy in kind (Scammell and Semetko 1995). Hence PEBs can be placed in the same category as other forms of political advertising. Paid media also covers the burgeoning sector of telephone and direct mail marketing, an increasingly common feature of contemporary election campaigning. Party colours, designs, slogan copy and symbols provide an additional dimension to the overall communications mix.

Free media refers to the publicity which parties receive but do not buy. In contrast to purchased advertising campaigns, organisations have less control 
over their product's exposure in the mass media. Consequently political strategists, not to mention the voting public, tend to view this kind of coverage as being of greater importance. Electoral organisations are becoming increasingly reliant on the techniques of news management. In recent years the American term "spin doctor" has entered the political lexicon in recognition of the increasing role that press, publicity and broadcasting officers can and do play in the British electoral and parliamentary process (Jones 1995). This aspect of campaigning provides perhaps one of the most striking contrasts between commercial and electoral marketing strategies: unlike their political counterparts, communications staff working for even the most senior corporate executives are unlikely to be deluged on a daily basis by some of the most experienced journalists eager for information and answers to highly sensitive questions.

Free media strategies are not solely concerned with defensive news management activities. More common to commerce and increasingly a part of the political process, public relations is a tool designed to attract favourable media attention for the organisation concerned. It is now almost obligatory for senior British politicians to participate in "photoopportunities”, news conferences and other scenarios designed to enhance the status of themselves and their message (Cockerell 1988; Franklin 1994). This is particularly true of the period in the run-up to an election.

Placement. 
At the heart of a placement or distribution strategy is a network of regional suppliers. In politics the equivalent form of organisation is the party at grassroots' level. Parties in Britain organise their membership and machinery on a regional and local basis. The executives of these bureaucracies help co-ordinate and supply volunteer labour and strategic inputs during election campaigns. In addition this network also liases with the national apparatus in order to devise and co-ordinate regional events and tours by the party leadership. It should be noted that, precisely because it is a political marketing "mix", some of the activities that may constitute part of one variable can be found in another. In this way the methods of the distribution policy closely mirror those of a promotional strategy in that both are reliant on tools such as direct mail despite having different aims (Farrell 1986).

Local electioneering commonly takes the form of traditional activities such as canvassing, leafleting and what American strategists call "getting the vote out” on polling day (Kavanagh 1970; Denver and Hands 1992). Contrary to some perceptions, most modern campaign canvassing is now more preoccupied with identifying and contacting potential and confirmed party supporters than it is with persuading them. This may derive from the fact that local activities have had to change due to a decline in the availability of volunteers coupled with the increasing desire of central headquarters to assert a common "brand” awareness in all party electoral communications. 
The post-war decline in grassroots' membership perhaps reflects an assumption that localised forms of campaigning are largely ineffectual. Such a view has been widely fostered in the United States where the use of political consultants has had an unfavourable effect on the strength of precinct organisation (Ware 1985; O’Shaughnessy 1990). However, recent research in Britain has begun to challenge the notion that local campaign work is ineffectual by demonstrating the potential electoral benefits of maintaining a healthy organisation at this level (Seyd and Whiteley 1992). Furthermore the implementation of new and more affordable forms of campaign technology may even increase the value of electoral initiatives at constituency level (Farrell and Wortmann 1987). Existing evidence suggests that computers, telephone canvass banks and direct mail initiatives became the norm in British by-elections before later establishing themselves as standard general election practice in most key marginal seats (Swaddle 1988).

Price.

Pricing, the fourth part of a conventional marketing mix, enables a commercial firm to develop a strategy which will help maintain competitiveness and profitability in the marketplace. Some electoral commentators have discounted the pricing element in the belief that it adds little to the analysis of campaign planning and implementation (Farrell 1986; Farrell and Wortmann 1987). Wangen takes the variable to mean the way an organisation raises campaign finance and attracts members (Wangen 1983). By contrast the theoretical basis of this paper is built on a conception of the 
political marketing process defined by Philip Niffenegger (1990) and which includes all the central tenets of conventional theory (see Table 1). Niffenegger justifies the relevance of the pricing mix by outlining its constituent parts. These elements, relating to environmental phenomena as interpreted by the electorate, comprise voter feelings of national, economic and psychological hope or insecurity. This notion of the political "price" reflects Reid's observation that a vote is a "psychological purchase" (Reid 1988). The parallels between electoral and consumer behaviour have been more comprehensively analysed by Lane (1993).

There are always problems inherent in designing campaigns according to market research findings. These pitfalls are augmented when candidates seek to capitalise on the reported anxieties or aspirations of a given electoral group. One public sign of the importance attached to this kind of strategy is the growth in "negative campaigning”. This type of electioneering, most commonly associated with American politics, involves attempts by party or candidates' organisations to frighten voters with robust and often startling denunciations of opponents. The frequency with which many leading national candidates in the United States have used this type of campaign has offended even David Ogilvy, a staunch defender and senior member of the marketing industry: "There is one category of advertising which is totally uncontrolled and flagrantly dishonest: the television commercials for candidates in Presidential elections” (Ogilvy 1983, p.209). 
Negative "appeals" usually focus on only one aspect of the pricing mix at a time. Depending on the audience being targeted, common economic themes include an opponents' intention to either raise tax and spending or else make sweeping budget cuts. In times of international insecurity or domestic uncertainty politicians, particularly incumbents, often stress their rivals' apparent lack of diplomacy or administrative competence. Such appeals are often couched in images which stress the need to counter what is posed as a threat to the "national interest" from "undesirable elements" be they at home or abroad. Perhaps the least tangential element of the pricing mix relates to the psychological cost implicit in voting. A popular feature in negative campaigns, such strategies tap into often deep seated and unspoken prejudices about a given politician's lack of ability, judgement and trustworthiness. As O'Keefe notes: “...in no other campaign situation are target audiences required to take into account not only ideas, issues, and policies, but also such human traits as honesty, professional expertise, and managerial style" (O'Keefe 1989). Famous victims of this type of attack advertising have included American presidential and vice-presidential hopefuls such as Barry Goldwater, Spiro Agnew, Michael Dukakis and Bill Clinton (Jamieson 1992).

"Pricing” policy need not necessarily form a wholly negative part of the political marketing mix. It is possible to conceive of a campaign strategy which promotes the idea of a domestic "feelgood factor" or boasts a perceived increase in the country's international standing in a order to make political capital and win votes. Similarly incumbent politicians often allude 
to psychological notions of "a nation at ease with itself” in their attempt to secure re-election. Despite the fact that pricing is the least tangible aspect of a marketing strategy, it is nevertheless a useful concept which complements the other variables. Precisely because it is a "mix", pricing can be seen to interlock and overlap with the other strategic tools, particularly those concerned with communications and product management. Marketing can be analysed in its constituent parts but should ultimately be seen in its totality.

Strategic Considerations: market research, segmentation and positioning. Market research plays an important role in modern electoral politics. Since its first recorded use by an American candidate in the 1930s, private polling has mushroomed both in terms of its expense and importance (HodderWilliams 1970; Teer and Spence 1973; Kavanagh 1992). The rise of opinion research offers party leaderships potential enlightenment but also a challenge. Political elites who were once able to rely on channels of mass communication to influence a captive public are now faced with commissioning often unedifying polling findings in order to help sharpen strategy and sustain their electoral good fortune (Wring 1996). In the past opinion research has commonly taken the form of quantitative based surveys of key demographic groups. More recently politicians have begun to employ consultants who specialise in the "psychographic" forms of private polling designed to explore voters’ more deep seated values and attitudes (Kleinman 1987; Worcester 1991). Increasingly campaign research studies are 
beginning to combine traditional quantitative research with focus groups and other types of qualitative methods.

Feedback in the form of opinion research is an important component in the design of an effective marketing mix. It also forms an integral part of the wider strategic process, helping to segment and target the market. Market segmentation takes place when an organisation uses research to divide available customers into categories according to their likely need or ability to purchase the firm's offering. Having identified key consumer segments, a marketing programme can then be targeted at defending or expanding current market share. Given their similar strategic aims, political strategists have also drawn on segmentation and targeting tools. Marketing analysis has pointed to the possible benefits to be derived from dividing voters according to demographic, psychographic or geographic criteria (Yorke and Meehan 1986; Smith and Saunders 1990). From the perspective of political science this trend has been exacerbated by psephological studies stressing the importance of parties' need to target the masses of uncommitted or "floating” voters in their bids to secure electoral victory (Miller et al. 1990).

In implementing marketing strategy, organisations use research to help them best position their offering in the market. The concept of positioning has a central place in political marketing analysis. Downs' classic study of party competition was based on a market model in which rival organisations maximised electoral support by moving themselves towards the electoral centreground (Downs 1957). This model has since become a popular 
analytical starting point for many strategists. More recently, other theorists have developed alternative concepts of positioning which emphasise the value of continuity in the electoral offering and the importance of leading as well as following opinion. In their work Smith and Saunders (1990) point to the potential political problems caused by "the flight to the centre" whereby parties fail to differentiate the brand values of their "product" through use of its Unique Selling Point (USP) or other positioning tools (Fletcher 1984).

In a marketing analysis of an American senatorial race, Schoenwald (1987) demonstrates the centrality of positioning theory to candidate image management. Similarly, in his groundbreaking work on political marketing, Gary Mauser places the concept at the core of his research (Mauser 1983). Developing a multi-dimensional scale, Mauser demonstrates how a candidate can use cluster analysis and other statistical methods to isolate those issues and attributes which unite partisans with potential voters in a common resolve. The logical consequence of this argument is that the adoption of marketing strategies does not necessarily mean the dilution of party ideology (see also O’Cass 1996), a view most amply demonstrated by the electoral success of the Thatcher and Reagan administrations.

\section{Conclusions.}

This paper has been concerned with demonstrating the usefulness of marketing analysis in the study of political campaigning. Having shown how the writings of democratic theorists might be reconciled with those of 
management scholars, a framework based on the basic '4Ps' marketing model was used in order to identify and explore the various elements that constitute an election campaign. Such an approach is arguably useful in analysing the increasingly marketing driven politics evident in many of the major western democracies.

\section{References.}

Biocca, F. (Ed),(1991), Television and Political Advertising: Volume 1, Psychological Processes, New York, Lawrence Erlbaum.

Blois, K.J. (1987), “Marketing for non-profit organizations”. In: The Marketing Book, (Ed) Baker, M.J., (London), Heinemann.

Bowler, S. and Farrell, D. (Eds), (1992), Electoral Strategy and Political Marketing, Hampshire, Macmillan.

Butler, D. and Ranney, A. (Eds), (1992), Electioneering: A Comparative Study of Continuity and Change, Oxford, Clarendon Press.

Butler, P. and Collins, N. (1993), “Campaigns, Candidates and Marketing in Ireland”, Politics, 13, No.1.

Cockerell, M. (1989), Live From No.10, London, Faber and Faber.

Crewe, I. and King, A. (1994), "Did Major Win? Did Kinnock Lose? Leadership Effects in the 1992 British General Election”. In: Labour's Last Chance?, (Eds) Heath, A. et al., (London), Dartmouth.

Denver, D. and Hands, G. (1992), “Constituency Campaigning”, Parliamentary Affairs, 45, pp. 528-544. 
Downs, A. (1957), An Economic Theory of Democracy, New York, Harper and Row.

Farrell, D. and Wortmann, M. (1987), "Parties strategies in the electoral market: Political marketing in West Germany, Britain and Ireland”, European Journal of Political Research, 15.

Farrell, D. (1986), “The Strategy to Market Fine Gael in 1981”, Irish Political Studies, 1, pp.1-14.

Fine, S. (Ed), (1992), Marketing the Public Sector: Promoting the Causes of Public and Non-Profit Agencies, New Brunswick, Transaction.

Fletcher, W. (1984), Commercial Breaks: insights into advertising and marketing, London, Advertising Press.

Foley, M. (1993), The Rise of the British Presidency, Manchester, Manchester University Press.

Franklin, R. (1994), Packaging Politics: Political Communications in Britain’s Media Democracy, London, Edward Arnold.

Galbraith, J.K. (1969), The Affluent Society, Harmondsworth, Penguin.

Gamble, A. (1974), The Conservative Nation, London, Routledge Kegan and Paul.

Graham, P. (1994), “Marketing in the Public Sector: Inappropriate or Merely Difficult?”, Journal of Marketing Management, 10, pp. 361-375.

Harrop, M. and Shaw, A. (1989), Can Labour Win?, London, Unwin in conjunction with the Fabian Society.

Harrop, M. (1986), "Voting and the Electorate”. In: Developments in British Politics, (Eds) H.Drucker et al., (London), Macmillan.

Harrop, M. (1990), “Political Marketing”, Parliamentary Affairs, 43, No.3. 
Himmelweit, H., Humphreys, P. and Jaeger, M. (1985), How Voters Decide, Milton Keynes, Open University Press.

Hodder-Williams, R.(1970), Public Opinion Polls and British Politics, London, Routledge and Kegan Paul.

Hooley, G., Lynch, J. and Shepherd, J. (1990), “The Marketing Concept:

Putting Theory into Practice”, European Journal of Marketing, 24, pp. 8-23.

Hunt, S.D. (1976), “The Nature and Scope of Marketing”, Journal of Marketing, 40, pp.17-28.

Jamieson, K.H. (1992), Dirty Politics: deception, distraction, and democracy, New York, Oxford University Press.

Jones, N. (1995), Soundbites and Spin Doctors: How politicians manipulate the media and vice versa, London, Cassell.

Kavanagh, D. (1970), Constituency Electioneering in Britain, London. Longman.

Kavanagh, D. (1992), "Private Opinion Polls and Campaign Strategy”, Parliamentary Affairs, 45, pp. 518-527.

Kelley, S. (1956), Professional Public Relations and Political Power, Baltimore, John Hopkins Press.

Kleinman, P. (1987), “The Research Market: Did psychographics win the General Election?”, Admap, September, pp. 16-18.

Kotler, P. and Levy, S.J. (1969), “Broadening the Concept of Marketing”, Journal of Marketing, 33, pp. 10-15.

Kotler, P. (1975), “Overview of Political Candidate Marketing”, Advances in Consumer Research, 2, pp. 761-769. 
Kotler, P. (1982), “Voter Marketing: Attracting Votes”. In: Marketing for Non-profit Organizations, Kotler, P., New Jersey, Prentice-Hall.

Lane, R. (1993), "Voting and Buying: Political Economy on the Small Stage”, paper presented at the Annual Meeting of the Society for the Advancement of Socio-economics, New York School for Social Research, New York, March.

Mauser, G. (1983), Political Marketing: an approach to campaign strategy, New York, Praegar.

McCarthy, E.J. (1960), Basic Marketing, Illinois, Richard D.Irwin.

Miller, W. et al. (1990), How Voters Change: the 1987 British election campaign in perspective, Oxford, Clarendon.

Mughan, A. (1993), "Party Leaders and Presidentialism in the 1992 election”. In: British Elections and Parties Yearbook 1993, (Eds) Denver, D. et al., London, Harvester Wheatsheaf.

Newman, B. and Sheth, J. (Eds), (1985), Political Marketing: Readings and Annotated Bibliography, Chicago, American Marketing Association.

Newman, B. (1994), Marketing the President, London, Sage.

Niffenegger, P. (1989), “Strategies for success from the political marketers”, Journal of Consumer Marketing, 6, pp. 45-51.

O’Cass, A. (1996), "Political marketing and the marketing concept”, European Journal of Marketing, 30, pp. 45-61.

Ogilvy, D. (1983), Ogilvy on Advertising, London, Pan.

O'Keefe, G.J. (1989), “Political Campaigns: Strategies and Tactics”. In: Information Campaigns, (Ed) Salmon, C.T., (Newbury Park), Sage. 
O'Leary, R. and Iredale, I. (1976), “The Marketing Concept: Quo Vadis?”, European Journal of Marketing, 10, pp. 146-57.

O'Shaughnessy, N.J. (1990), The Phenomenon of Political Marketing, Hampshire, Macmillan.

Qualter, T. (1985), Opinion Control in the Democracies, Hampshire, Macmillan.

Reid, D.(1988), "Marketing the Political Product”, European Journal of Marketing, 22, pp.34-47.

Rosenbloom, D.(1973), The Election Men: Professional Campaign Managers and American Democracy, New York, Quadrangle.

Sackman, A.(1992), “The Marketing Organisation Model: Making Sense of Modern Campaigning in Britain”, paper presented at the UK Political Studies Association Annual Conference, Belfast, April.

Scammell, M. and Semetko, H.(1995), "Political Advertising in Television:

The British Experience”. In: Political Advertising in Western Democracies, (Eds) Kaid, L.L. and Holtz-Bacha, C., (London), Sage.

Schattschneider, W. (1960), The Semi-Sovreign People, New York, Holt Rinehart.

Schoenwald, M. (1987), “Marketing a Political Candidate”, Journal of Consumer Marketing, 4, pp. 57-63.

Schumpeter, J. (1943), Capitalism, Socialism and Democracy, London, Urwin.

Scott, A.M. (1970), Competition in American Politics, New York, Holt, Rinehart and Winston. 
Seyd, P. and Whiteley, P. (1992), Labour's Grassroots: the Politics of Party Membership, Oxford, Clarendon.

Shama, A. (1974). "Political Marketing: A Study of Voter Decision-Making Process and Candidate Marketing Strategy”, in Annual Proceedings of the American Marketing Association, New York, American Marketing Association.

Shama, A. (1976), “The Marketing of Political Candidates”, Journal of the Academy of Marketing Sciences, 4, pp. 764-777.

Shaw, E. (1994), The Labour Party since 1979: Crisis and Transformation, London, Routledge.

Smith, G. and Saunders, J. (1990), “The Application of Marketing to British Politics”, Journal of Marketing Management, 5, pp. 295-306.

Swaddle, K. (1988), “Hi-Tech Elections: Technology and the Development of Electioneering since 1945”, Contemporary Record, Spring, pp. 32-35.

Tam, H. (Ed), (1994), Marketing, Competition and the Public Sector, Essex, Longman.

Teer, F. and Spence, J.D. (1973), Political Opinion Polls, London, Hutchinson.

Tyler, R. (1987), Campaign! The Selling of a Prime Minister, London, Grafton.

Wangen, E. (1983), Polit-Marketing: Das Marketing-Management der Politschein Partein, Opladen, Westdeutscher Verlag.

Ware, A. (1985), The Breakdown of Democratic Party Organization, 194080, Oxford, Clarendon Press. 
Wellhofer, E.S. (1990), “Contradictions in market models of politics: the case of party strategies and voter linkages”, European Journal of Political Research, 18, pp. 9-28.

Whyte, J. (1988), “Organization, person and idea marketing exchanges”. In: The Marketing Digest, (Eds) Thomas, M. and Waite, N., (London), Heinemann.

Wiebe, G.D. (1951), "Merchandising Commodities and Citizenship on Television”, Public Opinion Quarterly, 15, pp. 679-691.

Worcester, R. (1987) “The triangular equation behind the Tory victory”, The Times, 13th June.

Worcester, R. (1991), British Public Opinion, Oxford, Blackwell.

Wring, D. (1996), "From Mass Propaganda to Political Marketing: the Transformation of Labour Party Election Campaigning”. In: British Parties and Elections Yearbook 1995, (Eds) Broughton, D. et al., (London), Frank Cass.

Yorke, D.A. and Meehan, N. (1986), “Acorn in the political marketplace”, European Journal of Marketing, 20, pp. 63-76. 